\title{
Fertility in the Yamal-Nenets Autonomous Okrug
}

\author{
Vladimir N. Arkhangelsky ${ }^{1,2}$ \\ 1 Lomonosov Moscow State University, Moscow, 119991, Russia \\ 2 ISESP FCTAS RAS, Moscow, 117218, Russia
}

Received 27 February 2021 • Accepted 15 March 2021 • Published 09 April 2021

Citation: Arkhangelsky VN (2021) Fertility in the Yamal-Nenets Autonomous Okrug. Population and Economics 5(1): 72-89. https://doi.org/10.3897/popecon.5.e65207

\begin{abstract}
The article is devoted to the analysis of fertility indicators in the Yamal-Nenets Autonomous Okrug. Along with the total fertility rate for all births, the author traces the dynamics of birth order-specific fertility rates, as well as actual cohort fertility rates estimated by 2010 All-Russian census data. Particular attention is paid to the differences between these indicators in urban districts and municipal areas of the region. When considering the possible relationship of fertility indicators with the implementation of regional measures of demographic policy, special attention is paid to third and subsequent births, the level and dynamics of which can be influenced by the amount of regional maternal (family) capital, which is larger in the YamalNenets Autonomous Okrug than in other federal subjects of Russia. The results of the analysis show that the Yamal-Nenets Autonomous Okrug is among regions with a relatively high level and a young model of fertility. To a greater extent, this manifests itself in the second, third and subsequent births.
\end{abstract}

\section{Keywords}

age-specific fertility, demographic policy, order of birth, cohort fertility, total fertility rate, Yamal-Nenets Autonomous Okrug

JEL codes: J11, J13

\section{Introduction}

Fertility largely determines the mode of population reproduction, its natural growth, and therefore the dynamics of the population size in general.

In Russia, after almost collapsing in the 1990s, fertility slightly increased in the early 2000s. This increase intensified significantly since 2007, when new measures of pro-natal family policy, including the federal maternity (family) capital programme, were introduced. Accordingly, the increase in fertility since 2007 has affected second and subsequent births. The dynamics of fertility rates for first births are more related to changes in marriage rates 
(mainly for first marriages) and partly to the prevalence of postponement of first births in marriage.

The increase in fertility continued up until 2015, more precisely, until the beginning of autumn 2016 (refers to the dynamics of fertility indicators independent of the sex and age structure of the population, i.e. age-specific and total fertility rates; the absolute number of births and the total fertility rate began to decline slightly earlier due to the fact that small contingents of those born in the 1990s entered the active reproductive age). Fertility rates in Russia have been declining in recent years, but only for first and second births; for third and subsequent births they continue to rise.

The rate and trends of fertility in Russia have significant regional differences. Among the federal subjects of Russia with a relatively higher fertility rate is the Yamal-Nenets Autonomous Okrug. Some researchers even exclude it (with the caveat "in some years") from the number of regions in which there has been a transition to having few children (Zyryanova 2018). Nelly Smulyanskaya considers the Yamal-Nenets Autonomous Okrug among the regions with a transition model of fertility (Smulyanskaya 2017).

The purpose of this study is an in-depth analysis of the dynamics of fertility in the YamalNenets Autonomous Okrug from 1993 to the present and an assessment of changes in its age model. The analysis of the change in fertility rates by birth order allows to better evaluate the possible impact of family policy measures, since a large part of these measures are differentiated by the number of children.

\section{Fertility dynamics in the Yamal-Nenets Autonomous Okrug}

The crude birth rate in the Yamal-Nenets Autonomous Okrug is one of the highest in Russia. In 2019, it was 12.6 births per 1,000 population, which is much higher than the national average (10.1) or the average estimate for Ural Federal District (10.9).

According to preliminary data for 2020, higher values of the crude fertility rate than in the Yamal-Nenets Autonomous Okrug (13.0 per 1,000) were observed only in the Chechen Republic (20.2), the Republics of Tyva (20.0), Ingushetia (16.6), Dagestan (14.9), Altai (13.4) and Sakha (Yakutia) (13.3), as well as the Nenets Autonomous Okrug (13.4). In 2020, this rate increased in the Yamal-Nenets Autonomous Okrug for the first time since 2015. Only in the republics of Ingushetia, Kabardino-Balkar, Tyva and Chechen, as well as in Moscow region, the increase in the crude fertility rate in 2020 was slightly higher.

The higher value of the total fertility rate in the Yamal-Nenets Autonomous Okrug compared to the all-Russian level is determined by both the relatively higher age-specific fertility rates and a larger proportion of women of active reproductive age. The use of the index method shows that in 2019 the main contribution (77.3\%) to the excess of the total fertility rate in the Yamal-Nenets Autonomous Okrug above the all-Russian level was made by higher age-specific fertility rates. The contribution of a more favourable sex and age structure of the population was $22.7 \%$ respectively (for the use of the index method in relation to fertility indicators see (Fertility: system .. 2014)).

The total fertility rate (TFR) in the Yamal-Nenets Autonomous Okrug was 1.825 in 2019, which is much higher than average Russian indicator (1.504) or that of the Ural Federal Okrug (1.623). Estimated TFRs were higher only in the Tyva $(2,724)$, the Chechen Republic $(2,576)$, Altai $(2,114)$, Buryatia $(1,890)$ and Ingushetia $(1,826)$, Sakhalin Oblast $(1,954)$ and the Nenets Autonomous Okrug (2,176). 
In the 1990s the TFR in the Yamal-Nenets Autonomous Okrug, as well as in Russia generally, was decreasing (see Table 1). It reached its minimum in 2000 (in Russia as a whole in 1999). However, already in the early 2000s its value increased significantly, and in 2003 it was 0.282 higher than in 2000. For comparison, in general in Russia, its increase in this period amounted to 0.125 .

Table 1. TFR in the Yamal-Nenets Autonomous Okrug Okrug, 1993-2019

\begin{tabular}{ccccccccccccccc}
\hline Years & 1993 & 1994 & 1995 & 1996 & 1997 & 1998 & 1999 & 2000 & 2001 & 2002 & 2003 & 2004 & 2005 & 2006 \\
\hline TFR & 1.657 & 1.729 & 1.658 & 1.542 & 1.491 & 1.512 & 1.440 & 1.384 & 1.507 & 1.554 & 1.666 & 1.649 & 1.571 & 1.498 \\
\hline Years & 2007 & 2008 & 2009 & 2010 & 2011 & 2012 & 2013 & 2014 & 2015 & 2016 & 2017 & 2018 & 2019 & \\
\hline TFR & 1.609 & 1.652 & 1.743 & 1.785 & 1.836 & 2.053 & 2.090 & 2.189 & 2.188 & 2.084 & 1.948 & 1.895 & 1.825 & \\
\hline
\end{tabular}

Source: Demographic Yearbooks of Russia 2012-2105, 2017, 2019; Rosstat data

The increase of the TFR among the urban population of the Yamal-Nenets Autonomous Okrug was particularly significant. Its increment in 2000-2003 was 0.308 (among the rural population - 0.147).

In this regard, it is worth noting that on February 9, 1998 Law No. 7-LAO On State Youth Policy in the Yamal-Nenets Autonomous Okrug was adopted. Article 12, The right of young families to acquire their own homes, states: "Young families in need of housing shall be entitled in the event of birth of a child to receive subsidies for its purchase or construction". The resolution of the Governor of the Yamal-Nenets Autonomous Okrug of October 29, 2001 No. 651 approved the regional target programme Housing, as well as the programme Youth of Yamal for 2002-2003, which provided for assistance to young families in improving housing conditions. The Law of the Yamal-Nenets Autonomous Okrug of June 21, 2003 No. 39-LAO approved the district target programme Housing for young families.

Tatyana Kombarova, while analyzing the dynamics of fertility in the Tyumen region, draws attention to the growth of fertility in the Khanty-Mansi Autonomous Okrug since 2001, after the launch of the Governor's programme Young Family - Affordable Housing (Kombarova 2015), but does not consider a more significant increase in fertility during the start of a similar programme in the Yamal-Nenets Autonomous Okrug. As will be shown below, in the early 2000s, there was a significant increase in the fertility rate in the 20-24 age group in the Yamal-Nenets Autonomous Okrug.

In 2004-2006 the TFR in the district declined markedly again. A new significant increase occurred in 2007, when additional federal measures of state assistance to families with children were implemented. However, if in Russia as a whole the increase of the TFR in 2007 was much greater than in previous years, in the Yamal-Nenets Autonomous Okrug it was the same as in 2003 (by 0.112 in 2003 compared to 2002 and 0.111 in 2007 compared to 2006). It probably indicates the significance of the increase in the TFR in the Yamal-Nenets Autonomous Okrug in the early 2000s.

In general, in Russia, the largest increase in the TFR occurred in 2007, and in the YamalNenets Autonomous Okrug - in 2012 (by 0.217, which is almost double that of 2007).

In 2011, gathering of information on the distribution of births by order was restored in the Yamal-Nenets Autonomous Okrug, and from then on it is worth analysing the changes in the fertility rate using indicators of fertility according to the order of birth. It should only be noted that if in general in Russia the increase in the TFR continued until 2015, the maximum value in the Yamal-Nenets Autonomous Okrug was reached in $2014(2,189)$. In 2015, 
it decreased by 0.001 , and in the following years (especially in 2017) it decreased more significantly, and in 2019 its value was 1.825 , that is, 0.364 less than in 2014. However, judging by the increase in the crude fertility rate in the Yamal-Nenets Autonomous Okrug in 2020, we can expect an increase in the TFR to an even greater extent than the crude rate, since its increase was impeded by negative changes in the sex and age structure of the population, namely, a reduction in the proportion of women of active reproductive age.

Among the municipal districts of the Yamal-Nenets Autonomous Okrug, a relatively high TFR is observed in Tazovsky, Shuryshkarsky and Yamal districts and, conversely, lower - in Krasnoselkupsky, Nadymsky and Purovsky. The higher birth rate in the Tazov and Yamal districts due to ethnic peculiarities of reproductive behaviour of rural women was noted by the team of researchers of the Arctic Research Center (Andronov, et al. 2018).

Table 2. TFR in municipal districts and urban districts of the Yamal-Nenets Autonomous Okrug, 2014-2017

\begin{tabular}{lcccc|lllll}
\hline $\begin{array}{l}\text { Municipal } \\
\text { Districts }\end{array}$ & $\mathbf{2 0 1 4}$ & $\mathbf{2 0 1 5}$ & $\mathbf{2 0 1 6}$ & $\mathbf{2 0 1 7}$ & $\begin{array}{l}\text { Urban } \\
\text { Districts }\end{array}$ & $\mathbf{2 0 1 4}$ & $\mathbf{2 0 1 5}$ & $\mathbf{2 0 1 6}$ & $\mathbf{2 0 1 7}$ \\
\hline Krasnoselkupsky & 2.877 & 2.894 & 2.746 & $\mathbf{1 . 8 7 5}$ & Salekhard & 2.008 & 2.014 & 1.857 & 1.640 \\
Nadymsky & 1.888 & 1.905 & 1.866 & 1.764 & Gubkinskiy & 1.858 & 1.855 & 1.782 & 1.616 \\
Priuralsky & 3.237 & 3.443 & 3.103 & 2.981 & Labytnangi & 2.308 & 2.012 & 2.035 & 2.001 \\
Purovsky & 2.201 & 2.157 & 1.989 & 1.764 & Muravlenko & 2.107 & 2.164 & 1.979 & 1.865 \\
Tazovsky & 3.431 & 3.429 & 3.325 & 3.296 & Novy Urengoy & 2.062 & 1.956 & 1.858 & 1.804 \\
Shuryshkarskiy & 3.830 & 4.076 & 3.122 & 3.738 & Noyabrsk & 1.972 & 1.972 & 1.918 & 1.729 \\
Yamalsky & 3.908 & 3.734 & 3.435 & 3.408 & & & & & \\
\hline
\end{tabular}

Source: author's calculations according to Rosstat data

Urban districts are more homogeneous in terms of the TFR. In 2017, it was slightly lower in Gubkinsky and Salekhard than in others, and the highest was in Labytnangi (Table 2).

\section{Birth order-specific fertility}

A significant increase in the value of the TFR in the Yamal-Nenets Autonomous Okrug in 2012 was observed in birth of all order. Maximum growth was observed in second births (by 0.093), and in third births (by 0.056) the increase was almost equal to that in first births (by 0.059; see Table 3). At the same time, the relative increase in the TFR for third births in 2012 was the largest among all birth orders.

The absolute increase in the TFR for third births in 2012 in the Yamal-Nenets Autonomous Okrug was the largest among all the federal subjects of the Russia.

This dynamic may be associated with the introduction of regional measures to support large families (Muzykina 2015).

Thus, Law No. 73-LAO in the Yamal-Nenets Autonomous Okrug established the largest amount of maternal (family) capital among all Russian regions - 350 thousand rubles in the case of birth (adoption) of a third child or subsequent children. The possible relationship between the size of regional maternal (family) capital and the significant growth of the TFR 
for third and subsequent births has already been highlighted in one of our papers (Arkhangelsky, Dzhanaeva 2014).

In 2019, the amount of regional maternal (family) capital was increased to 500 thousand rubles by the law of the Yamal-Nenets Autonomous Okrug No. 87-LAO. The possible impact of this increase could be estimated by the change in the value of the TFR for third and subsequent births in 2021.

In addition to the regional maternal (family) capital in the Yamal-Nenets Autonomous Okrug, there is a monthly benefit paid in the amount of the child subsistence minimum at the birth of a third or subsequent child up to the age of 3 (for families whose average per capita income does not exceed twice the subsistence minimum of the working population). This programme was launched in January, 2013.

In 2013, the growth of TFR for third and subsequent births (by 0.025) in the YamalNenets Autonomous Okrug was significantly lower than in 2012 (by 0.065). Apparently, this could have been expected, as two measures aimed at supporting third and subsequent births - regional maternal (family) capital and monthly benefit - were implemented with a 1-year gap between them. Those two-child families, which were not generally opposed to having a third child, probably reacted with giving this birth in 2012, when the regional maternal (family) capital was introduced. The monthly benefit might possibly have had a more significant impact on fertility had its implementation begun later, when the possible decision on the birth of the third child would have been made by new two-child families. The fact that the increase in the TFR for third and subsequent births in 2014 (by 0.048) was almost double compared to that of 2013 (by 0.025), but still less than in $2012(0.065$; see Table 3), could be seen as indirect confirmation of this logic.

The TFR for first births in 2013-2014 in the Yamal-Nenets Autonomous Okrug was abnormally high (0.965). At the same time, in the rural population in 2011-2015 it exceeded 1.0, which, of course, can be only in calendar cohorts. There were probably shifts in the birth calendar (timing) manifested in the earlier birth of the first child. After such timing shifts, there will inevitably be decline, entailing a sharp reduction in the value of the indicator, which was observed in actual data in 2016-2019. To the greatest extent, such a timing decline for first births was manifested in the TFR among the rural population. The value of this indicator for first births decreased from 1.138 in 2014 to 0.691 in 2019 (by 0.447), and among the urban population over the same period - from 0.922 to 0.664 (by 0.258 ), that is, to a much lesser extent.

In addition, in 2016, the Yamal-Nenets Autonomous Okrug recorded a significant decrease $(13.1 \%)$ in the number of registered marriages compared to the previous year; this usually entails a decrease in fertility rates by first births. Numner of marriages increased by $9.8 \%$ in 2017 , but dropped again in 2018, and to a much greater extent than in 2016 (by 22.8\%).

The TFR for second births decreased slightly in 2013 but increased significantly in 20142015. We might assume that the timing shifts manifested themselves in the earlier birth of the second child due to the anticipated completion of the federal maternal (family) capital programme in 2016. If so, the announcement of the extension of the federal maternal (family) capital programme in the Address of the President of the Russian Federation to the Federal Assembly on December 3, 2015 could stop timing shifts for at least two years. The ensuing decline is likely to be seen now in birth indicators for second births. A significant decrease in fertility began not in 2017, as is generally believed, but in the autumn of 2016 . In January-August 2016, the number of births in the Yamal-Nenets Autonomous Okrug decreased by $0.7 \%$ compared to the same period of 2015 and it was due to changes in the sex and age structure of the population. In September-December 2016, though, the number 
Table 3. Order-specific total fertility rates in the Yamal-Nenets Autonomous Okrug, 2011-2019

\begin{tabular}{|c|c|c|c|c|c|}
\hline Years & first births & second births & third births & fourth births & $\begin{array}{l}\text { fifth and } \\
\text { subsequent } \\
\text { births }\end{array}$ \\
\hline \multicolumn{6}{|c|}{ Total population } \\
\hline 2011 & 0.890 & 0.648 & 0.193 & 0.061 & 0.044 \\
\hline 2012 & 0.949 & 0.741 & 0.249 & 0.066 & 0.048 \\
\hline 2013 & 0.965 & 0.737 & 0.274 & 0.065 & 0.048 \\
\hline 2014 & 0.965 & 0.787 & 0.305 & 0.075 & 0.057 \\
\hline 2015 & 0.908 & 0.834 & 0.320 & 0.075 & 0.052 \\
\hline 2016 & 0.858 & 0.777 & 0.305 & 0.088 & 0.057 \\
\hline 2017 & 0.776 & 0.702 & 0.319 & 0.089 & 0.062 \\
\hline 2018 & 0.721 & 0.669 & 0.333 & 0.107 & 0.065 \\
\hline 2019 & 0.678 & 0.633 & 0.344 & 0.099 & 0.071 \\
\hline Russia, 2019 & 0.638 & 0.531 & 0.229 & 0.069 & 0.037 \\
\hline \multicolumn{6}{|c|}{ Urban population } \\
\hline 2011 & 0.849 & 0.621 & 0.161 & 0.037 & 0.014 \\
\hline 2012 & 0.909 & 0.704 & 0.218 & 0.048 & 0.014 \\
\hline 2013 & 0.902 & 0.690 & 0.237 & 0.041 & 0.018 \\
\hline 2014 & 0.922 & 0.742 & 0.263 & 0.050 & 0.022 \\
\hline 2015 & 0.850 & 0.796 & 0.273 & 0.049 & 0.019 \\
\hline 2016 & 0.828 & 0.737 & 0.264 & 0.060 & 0.024 \\
\hline 2017 & 0.754 & 0.655 & 0.278 & 0.059 & 0.024 \\
\hline 2018 & 0.708 & 0.636 & 0.285 & 0.074 & 0.027 \\
\hline 2019 & 0.664 & 0.587 & 0.292 & 0.068 & 0.031 \\
\hline \multicolumn{6}{|c|}{ Rural population } \\
\hline 2011 & 1.058 & 0.773 & 0.394 & 0.216 & 0.255 \\
\hline 2012 & 1.113 & 0.922 & 0.427 & 0.185 & 0.270 \\
\hline 2013 & 1.264 & 0.979 & 0.492 & 0.210 & 0.242 \\
\hline 2014 & 1.138 & 1.007 & 0.537 & 0.227 & 0.282 \\
\hline 2015 & 1.133 & 0.978 & 0.590 & 0.235 & 0.261 \\
\hline 2016 & 0.936 & 0.932 & 0.530 & 0.251 & 0.277 \\
\hline 2017 & 0.814 & 0.904 & 0.532 & 0.269 & 0.312 \\
\hline 2018 & 0.708 & 0.788 & 0.591 & 0.308 & 0.317 \\
\hline 2019 & 0.691 & 0.829 & 0.630 & 0.290 & 0.338 \\
\hline
\end{tabular}

Source: author's calculations according to Rosstat data

of births decreased by $13.4 \%$ compared to 2015 . The largest decrease in the TFR for second births occurred in 2017 (by 0.075), and in 2018 and 2019 this indicator decreased by 0.033 and 0.036 respectively. 
Timing shifts for second births probably reflected the dynamics of the TFR among rural populations to a greater extent than in urban ones. This may be due to the significant timing shifts noted above for first births in rural populations. After several years during which the TFR for first births exceeded the value of 1.0, in 2014 the value of the TFR for second births in the rural population also exceeded 1.0, and in 2013 and 2015 it was very close to that level (0.98). If the urban population of the Yamal-Nenets Autonomous Okrug experienced the main decrease in the TFR for second births in 2017 (by 0.082), and in 2018 the reduction was small (by 0.019 ; but significantly larger in 2019 - by 0.049 ), the rural population, on the contrary, experienced a relatively small (by 0.028) decrease in the value of this indicator in 2017, and a very significant in 2018 (by 0,116). In 2019, the TFR for second births in the rural population increased by 0.041 .

Indirect evidence in favour of the fact that the significant decline of the TFR for second births in recent years is primarily due to timing failure, rather than socioeconomic reasons, is that there was no positive dynamics of the TFR for third and subsequent births. In 2018, the increase in this indicator was the largest since 2015, and its value (0.505) was 69.5\% higher than in 2011. In 2019, it increased to 0.514. If the decline of the TFR for second births was due to socioeconomic reasons, they would be highly likely to determine the decrease in the value of this indicator for third and subsequent births as well.

At the same time, there probably could not have been timing shifts on third and subsequent births due to the terms of the federal maternal (family) capital programme. The fact is that this capital can be claimed at the birth of a third or subsequent child only if this right has not previously been exercised. This means that the mother's second child should have been born before 2007, that is, the interval between the birth of the second and third child in 2014-2015 should be at least 8-9 years. It is likely that the number of third births at such a large interval is very low, especially if the region provides generous support for families at the birth of a third child, which is the case in the Yamal-Nenets Autonomous Okrug.

In conclusion to this part of the analysis, we should note that in 2019 the TFR in the Yamal-Nenets Autonomous Okrug was significantly higher than in Russia overall for all birth orders (Table 3 ).

\section{Age-specific fertility in the Yamal-Nenets Autonomous Okrug}

As in general in Russia, the highest intensity of fertility in the Yamal-Nenets Autonomous Okrug is observed among women aged 25-29 years. The peak of fertility in this age group is more pronounced than in the country as a whole. In general, in Russia in 2019, the fertility rate of 25-29-year-old women was $21.9 \%$ more than that of 20-24-year-olds, and $27.4 \%$ more than that of 30-34-year-olds. In the Yamal-Nenets Autonomous Okrug, it was higher by $60.1 \%$ and $55.4 \%$, respectively.

Characterizing the dynamics of age-specific fertility rates in the Yamal-Nenets Autonomous Okrug, we should, first of all, note the very significant increase in the birth rate in the 20-24 age group in the early 2000s. In 2004, its value was $24.1 \%$ higher than in 2000 (Table 4 ).

Almost none of the regions of Russia had such a significant increase in the birth rate in the 20-24 age group (except the Nenets and Chukotka Autonomous Okrugs, where, due to relatively small numbers, random fluctuations in indicators may occur). In general, in Russia, the birth rate in the 20-24 age group increased by $4.2 \%$ in 2002 compared to 1999 (since 2003 this indicator has been decreasing). 
Table 4. Age-specific fertility rates in the Yamal-Nenets Autonomous Okrug, 1993-2019

\begin{tabular}{|c|c|c|c|c|c|c|c|}
\hline \multirow{2}{*}{ Years } & \multicolumn{7}{|c|}{ Number of births per 1,000 women aged (years): } \\
\hline & 15-19 & 20-24 & $25-29$ & $30-34$ & $35-39$ & $40-44$ & 45-49 \\
\hline 1993 & 49.6 & 150.8 & 73.9 & 33.3 & 12.9 & 4.1 & 0.5 \\
\hline 1994 & 52.2 & 148.5 & 85.2 & 38.7 & 13.7 & 3.4 & 0.2 \\
\hline 1995 & 44.4 & 135.1 & 91.3 & 39.1 & 14.6 & 3.3 & 0.3 \\
\hline 1996 & 39.3 & 116.8 & 86.1 & 41.9 & 16.5 & 4.3 & 0.2 \\
\hline 1997 & 39.5 & 108.3 & 85.1 & 42.9 & 15.6 & 3.3 & 0.4 \\
\hline 1998 & 35.8 & 108.2 & 87.5 & 46.9 & 17.4 & 3.8 & 0.3 \\
\hline 1999 & 33.7 & 104.2 & 80.2 & 46.1 & 16.4 & 4.4 & 0.2 \\
\hline 2000 & 31.0 & 98.3 & 75.7 & 47.0 & 17.5 & 4.3 & 0.3 \\
\hline 2001 & 35.2 & 105.7 & 82.4 & 51.5 & 19.3 & 3.8 & 0.2 \\
\hline 2002 & 32.6 & 111.3 & 83.4 & 52.9 & 21.0 & 4.4 & 0.2 \\
\hline 2003 & 32.4 & 121.2 & 93.0 & 53.6 & 22.0 & 4.1 & 0.1 \\
\hline 2004 & 28.7 & 122.0 & 90.8 & 58.0 & 22.8 & 3.9 & 0.3 \\
\hline 2005 & 28.3 & 108.1 & 91.1 & 59.6 & 22.9 & 4.0 & 0.2 \\
\hline 2006 & 27.1 & 97.9 & 89.0 & 56.8 & 24.8 & 5.3 & 0.1 \\
\hline 2007 & 31.4 & 97.8 & 97.5 & 64.2 & 28.8 & 4.3 & 0.3 \\
\hline 2008 & 29.5 & 98.8 & 99.6 & 68.1 & 30.4 & 6.0 & 0.2 \\
\hline 2009 & 31.3 & 101.3 & 107.5 & 71.5 & 31.8 & 6.7 & 0.1 \\
\hline 2010 & 28.3 & 103.0 & 111.3 & 74.7 & 31.9 & 6.7 & 0.1 \\
\hline 2011 & 29.0 & 113.6 & 108.0 & 71.5 & 34.4 & 6.6 & 0.2 \\
\hline 2012 & 29.0 & 135.9 & 113.7 & 82.6 & 39.8 & 7.3 & 0.4 \\
\hline 2013 & 26.2 & 141.9 & 120.7 & 77.3 & 40.4 & 9.2 & 0.3 \\
\hline 2014 & 25.7 & 146.5 & 127.4 & 83.4 & 43.8 & 8.7 & 0.1 \\
\hline 2015 & 26.1 & 133.1 & 135.4 & 88.8 & 39.1 & 9.8 & 0.4 \\
\hline 2016 & 20.8 & 114.3 & 140.1 & 84.9 & 39.8 & 8.5 & 0.3 \\
\hline 2017 & 19.2 & 97.2 & 139.1 & 78.4 & 40.3 & 8.9 & 0.3 \\
\hline 2018 & 15.9 & 86.7 & 141.2 & 80.2 & 41.7 & 9.4 & 0.6 \\
\hline 2019 & 12.6 & 82.3 & 131.8 & 84.8 & 40.1 & 9.5 & 0.4 \\
\hline
\end{tabular}

Source: Rosstat data

The decline in the birth rate in the 1990s was accompanied by the ageing of the fertility model. If in the 15-19 and 20-24 age groups, birth rates fell by $37.5 \%$ and $34.8 \%$ respectively between 1993 and 2000, while in older ages they increased. In the 25-29 age group in 2000 the fertility rate was higher than in 1993 by $2.4 \%$, in the group of 30-34-year-olds by $41.1 \%$ (if in 1993-1995 the fertility rate for 30-34-year-old women was lower than for $15-19$-year-olds, in the following years it was higher), in $35-39$-year-olds - by $35.7 \%$, in 40-44-year-olds - by $4.9 \%$.

In the following years, ageing of the fertility model in the Yamal-Nenets Autonomous Okrug continued. It was particularly evident since 2007, when additional measures of state assistance to families with children aimed at supporting second and subsequent births began 
to be implemented. If in the 20-24 age group the fertility rate in 2007 was slightly $(0.1 \%)$ lower than in 2006, it was $9.6 \%$ higher in the $25-29$ age group, $13.0 \%$ in the $30-34$ age group, and $16.1 \%$ in the $35-39$ age group.

In 2008, the fertility rate for 25-29-year-old women exceeded that of 20-24-year-olds for the first time, and in the age of 35-39 years the rate exceeded that of 15-19-year-olds.

While in general in Russia after 2006 the fertility rate in the 20-24 age group changed only slightly, in the Yamal-Nenets Autonomous Okrug by 2014 it exceeded the level of 2007 by 1.5 times. This increment was greater than in the 25-29 age groups (by $30.7 \%$ ) and the 30-34 age group (by 29.9\%). As a result, in 2011-2014, the fertility rate for 20-24-year-olds was again higher than that of 25-29-year-olds. However, by 2017, this figure went down by a third (by $33.7 \%$ ) compared to 2014. At the same time, the fertility rate in the 25-29 age group, after a long period of almost consistent increase in 2017 , decreased only slightly (by $0.7 \%$ ) compared to 2016 . In 2018 , the fertility rate in the $20-24$ age group declined significantly again, and in older ages, on the contrary, increased. In 2019, the fertility rate for both 20-24-year-old and 25-29-year-old women decreased slightly (Table 4).

In recent years, the Yamal-Nenets Autonomous Okrug has seen a very pronounced accumulation of births in the 25-29 age group. In 2019, the fertility rate in this age group accounted for $36.5 \%$ of all age coefficients, while in Russia overall - for $30.3 \%$.

The characteristics of the age model of fertility in general for all births depend on the fertility rate as well as the proportion of second, third, and subsequent births. The higher it is, all other things being equal, the higher the proportion of birth rates in relatively older reproductive ages and the average age of the mother at birth of all children, regardless of the order of birth. A more correct analysis of the age model of fertility involves consideration of its indicators differentiated by the priority of birth.

Age-specific birth rates for first births have decreased significantly in recent years in the 15-19 age groups (2.4 times in 2019 compared to 2011) and among 20-24-year-olds (by $47.2 \%$ in 2019 compared to 2013), and increased slightly for older women (in the age group 25-29 years the rate has been increasing until 2016; in the age group 30-34 years it decreased slightly in 2017-2018, but in 2019 it was the highest since 2011). If, until 2015, the fertility rate for first births in the 20-24 age group was significantly higher than in 25-29 years, the difference between them decreased in the following years, and in 2018 and 2019 the fertility rate for first births in the age group 25-29 years was already higher than in 20-24 years (Table 5).

Thus, we can see ageing of fertility for first births in the Yamal-Nenets Autonomous Okrug. Compared to the all-Russian level in 2019, fertility rates for first births in the age groups 20-24 and 25-29 years were higher, but lower in 30-34 years and 35-39 years. That is, the age model of fertility for first births in the district is slightly younger than in Russia overall.

Maximum values of the fertility rate for second births in the Yamal-Nenets Autonomous Okrug were observed in the 25-29 age group. This figure increased up until 2016 (compared to 2011 by $25.8 \%$ ) and decreased in $2017-2019$. This decrease (by $16.5 \%$ in 2019 compared to 2016 ) was lower than in the $20-24$ age group $(32.4 \%)$. The reduction in the ratio in the ages of 30-34 (by 12.9\% in 2016-2019) and 35-39 years (by 7.1\%) was even smaller.

At the same time, there has been no significant change in relation to second births in recent years. Compared to Russia as a whole, in the Yamal-Nenets Autonomous Okrug birth rates for second births are higher in the 20-24 age group (by 20.4\%), 25-29 age group (by $36.7 \%$ ) and $30-34$ age group (by 14.8\%), but lower in 35-39 age group and 40-44 age group. Consequently, for second births, the age model of fertility in the Yamal-Nenets Autonomous Okrug is slightly younger than in the country overall. 
Table 5. Age-specific fertility rates according to birth order in the Yamal-Nenets Autonomous Okrug, 2011-2019

\begin{tabular}{|c|c|c|c|c|c|c|c|}
\hline \multirow{2}{*}{ Years } & \multicolumn{7}{|c|}{ Number of births per 1,000 women aged (years): } \\
\hline & $15-19$ & $20-24$ & $25-29$ & $30-34$ & $35-39$ & $40-44$ & $45-49$ \\
\hline \multicolumn{8}{|c|}{ first births } \\
\hline 2011 & 26.7 & 80.1 & 48.2 & 12.7 & 4.3 & 0.5 & 0.0 \\
\hline 2012 & 25.5 & 92.1 & 49.3 & 13.9 & 3.7 & 0.7 & 0.0 \\
\hline 2013 & 24.0 & 93.7 & 51.4 & 14.9 & 3.9 & 0.9 & 0.0 \\
\hline 2014 & 22.7 & 93.0 & 54.1 & 14.2 & 4.7 & 0.6 & 0.0 \\
\hline 2015 & 23.1 & 79.4 & 54.5 & 15.0 & 3.4 & 0.8 & 0.0 \\
\hline 2016 & 18.8 & 69.1 & 56.3 & 15.5 & 4.5 & 0.8 & 0.0 \\
\hline 2017 & 16.3 & 59.0 & 55.0 & 14.5 & 4.1 & 0.7 & 0.0 \\
\hline 2018 & 13.9 & 52.5 & 53.3 & 14.5 & 4.9 & 0.8 & 0.1 \\
\hline 2019 & 11.0 & 49.5 & 51.0 & 16.0 & 3.6 & 1.5 & 0.1 \\
\hline Russia, 2019 & 12.7 & 48.1 & 39.8 & 17.7 & 6.3 & 1.3 & 0.1 \\
\hline \multicolumn{8}{|c|}{ second births } \\
\hline 2011 & 2.1 & 27.4 & 45.4 & 39.2 & 14.5 & 2.1 & 0.0 \\
\hline 2012 & 3.3 & 34.7 & 49.8 & 43.2 & 16.6 & 2.1 & 0.1 \\
\hline 2013 & 2.2 & 39.3 & 50.9 & 38.0 & 15.6 & 2.5 & 0.1 \\
\hline 2014 & 2.7 & 42.4 & 52.5 & 41.7 & 16.6 & 2.5 & 0.0 \\
\hline 2015 & 2.7 & 43.7 & 56.6 & 45.8 & 14.8 & 2.6 & 0.1 \\
\hline 2016 & 1.8 & 36.7 & 57.1 & 41.8 & 14.1 & 2.3 & 0.1 \\
\hline 2017 & 2.7 & 28.7 & 55.5 & 36.1 & 14.2 & 2.4 & 0.1 \\
\hline 2018 & 1.9 & 25.6 & 55.2 & 34.8 & 13.8 & 2.2 & 0.1 \\
\hline 2019 & 1.4 & 24.8 & 47.7 & 36.4 & 13.1 & 2.2 & 0.1 \\
\hline Russia, 2019 & 1.7 & 20.6 & 34.9 & 31.7 & 14.9 & 2.8 & 0.1 \\
\hline \multicolumn{8}{|c|}{ third births } \\
\hline 2011 & 0.2 & 4.8 & 10.2 & 12.3 & 9.5 & 1.8 & 0.1 \\
\hline 2012 & 0.1 & 7.5 & 10.7 & 17.1 & 12.7 & 2.2 & 0.0 \\
\hline 2013 & 0.1 & 6.9 & 13.4 & 17.9 & 14.2 & 3.0 & 0.1 \\
\hline 2014 & 0.3 & 9.1 & 15.4 & 19.4 & 14.2 & 2.9 & 0.0 \\
\hline 2015 & 0.2 & 8.6 & 18.2 & 20.0 & 14.0 & 3.3 & 0.0 \\
\hline 2016 & 0.3 & 7.3 & 18.4 & 19.1 & 12.7 & 2.9 & 0.1 \\
\hline 2017 & 0.2 & 7.8 & 19.6 & 19.2 & 13.9 & 3.1 & 0.0 \\
\hline 2018 & 0.1 & 6.9 & 22.7 & 20.2 & 13.4 & 3.5 & 0.1 \\
\hline 2019 & 0.2 & 6.7 & 23.6 & 20.7 & 14.5 & 3.1 & 0.0 \\
\hline Russia, 2019 & 0.2 & 4.9 & 11.7 & 15.3 & 11.2 & 2.7 & 0.1 \\
\hline
\end{tabular}

Source: author's calculations according to Rosstat 
For third births, the largest fertility rate in the Yamal-Nenets Autonomous Okrug in 2019 was in the age group of 25-29 years. This was the result of its significant increase in recent years: in 2019 it was 2.3 times higher than in 2011. At the same time, in the 30-34 age group, the main increase in the fertility rate for third births occurred in 2012 (by 39.0\%), in the following years its growth was much smaller, and since 2015 the value of this coefficient has almost stabilized. As a result, if in 2012 the fertility rate for third births in the 30-34 age group was 59.8\% higher than that of the 25-29 years age group, in 2019, for 25-29-year-old women the value of this figure was $14.0 \%$ more than for 30-34-year-olds.

In the Yamal-Nenets Autonomous Okrug, the age model of fertility for third births is significantly younger than the country's overall. In Russia, the highest fertility rate for third births in 2019 was in the age group of 30-34 years, and in 35-39-year-olds it hardly differed from 25-29-year-olds. In the Yamal-Nenets Autonomous Okrug, as already noted, the highest fertility rate for third births in 2019 was in the 25-29 age group, while in 35-39-yearolds it was $38.6 \%$ lower than in 25-29-year-olds, and 30.0\% lower than in 30-34-year-olds (Table 5).

A generalizing indicator of the age model of fertility is the average age of the mother at birth of children (Table 6).

Table 6. Average age of the mother at birth of children according to birth order in the Yamal-Nenets Autonomous Okrug, 2011-2019, years

\begin{tabular}{lccccc}
\hline Years & first births & second births & third births & fourth births & $\begin{array}{l}\text { fifth and } \\
\text { subsequent } \\
\text { births }\end{array}$ \\
\hline 2011 & 24.14 & 29.11 & 31.59 & 32.61 & 34.61 \\
2012 & 24.14 & 28.96 & 31.67 & 33.01 & 34.61 \\
2013 & 24.31 & 28.61 & 31.92 & 32.23 & 34.78 \\
2014 & 24.48 & 28.63 & 31.37 & 32.54 & 34.85 \\
2015 & 24.69 & 28.56 & 31.34 & 32.66 & 34.46 \\
2016 & 25.08 & 28.61 & 31.16 & 31.90 & 34.76 \\
2017 & 25.27 & 28.81 & 31.23 & 31.78 & 34.07 \\
2018 & 25.46 & 28.92 & 31.26 & 32.26 & 34.25 \\
2019 & 25.83 & 29.20 & 31.29 & 32.28 & 33.87 \\
Russia, 2019 & 25.94 & 29.66 & 31.97 & 32.95 & 34.45 \\
\hline
\end{tabular}

Source: author's calculations according to Rosstat data

The average age of a mother at the birth of the first child in the Yamal-Nenets Autonomous Okrug is constantly increasing. In 2019, it was 25.8 years and increased by 1.7 years compared to 2011. However, in comparison with Russia as a whole, residents of the YamalNenets Autonomous Okrug have the first child born a little earlier (according to 2019 - by 0.11 years; see Table 6 ).

The average age of a mother at the birth of a second child in the Yamal-Nenets Autonomous Okrug decreased by 0.55 years by 2015 compared to 2011, and increased in subsequent years, and was already higher in 2019 than in 2011. Perhaps this dynamic is related to the timing shifts for second births described above. The age of the mother at the birth of the 
second child in 2019 in the Yamal-Nenets Autonomous Okrug was almost 0.5 years lower than in the Russian Federation as a whole (Table 6).

Finally, the average age of a mother at the birth of a third child in the Yamal-Nenets Autonomous Okrug increased in 2012-2013, but then declined substantially by 2016 and only slightly increased in 2017-2019. In 2019, this indicator in the Yamal-Nenets Autonomous Okrug was 0.68 years lower than in the Russian Federation as a whole.

\section{Actual cohort fertility indicators}

All fertility rates discussed above refer to calendar years. They can be calculated using vital statistics data, but their dynamics can be influenced by timing shifts manifested in earlier births due to a situation that was more birth-friendly but limited in time, or, on the contrary, in postponing the birth of children for various reasons.

Using actual cohort fertility rates allows avoiding the influence of timing shifts. However, timing shifts can still be reflected in the cumulative indicator - the number of children born to a woman by a certain age. At the same time, it is clear that the total number of children born will refer to generations that were at active reproductive age 10-15 years ago and will therefore serve rather as an indicator of fertility in past periods. Apart from that, data on the number of children born are given primarily by population censuses, which are conducted in Russia about once every 10 years. The most recent census (to date) was conducted in 2010 and could hardly reflect the possible impact of additional measures of assistance to families with children, introduced in 2007 or later, on the number of children born in actual cohorts of women.

Using data from the 2015 microcensus, which can also provide some estimations of fertility rates for actual cohorts, is not advisable because these data contradict the results of the 2010 Census - perhaps due to the fact that the microcensus covered only $1.5 \%$ of the population (Table 7).

Table 7. Average number of children born in the cohorts of women born in 1960-1970 in the YamalNenets Autonomous Okrug according to the 2010 Census and the microcensus of 2015, per woman

\begin{tabular}{lccccccccccc}
\hline \multirow{2}{*}{ Data Source } & \multicolumn{10}{c}{ Year of birth of women } \\
\cline { 2 - 14 } & $\mathbf{1 9 6 0}$ & $\mathbf{1 9 6 1}$ & $\mathbf{1 9 6 2}$ & $\mathbf{1 9 6 3}$ & $\mathbf{1 9 6 4}$ & $\mathbf{1 9 6 5}$ & $\mathbf{1 9 6 6}$ & $\mathbf{1 9 6 7}$ & $\mathbf{1 9 6 8}$ & $\mathbf{1 9 6 9}$ & $\mathbf{1 9 7 0}$ \\
\hline 2010 Census & 1.91 & 1.91 & 1.91 & 1.90 & 1.86 & 1.86 & 1.86 & 1.85 & 1.79 & 1.77 & 1.73 \\
2015 microcensus & 1.89 & 1.87 & 1.93 & 1.71 & 1.77 & 1.84 & 1.84 & 1.74 & 1.77 & 1.71 & 1.86 \\
\hline
\end{tabular}

Source: author's calculations according to the 2010 All-Russian Census and the 2015 microcensus.

Comparison of the average number of children born in women of the same year of birth according to the 2010 Census and the 2015 microcensus shows that in almost all cohorts born in the 1960s (except 1962) the value of this indicator decreased between 2010 and 2015 (Table 7). It seems that this may be due only to the incomparability of cohorts of women, for whom the average number of children born according to the Census and the microcensus is calculated. The discrepancy of data on the number of children born according to the 2010 Census and the microcensus of 2015 was emphasized by other researchers (Andreev, Zakharov 2017; Monitoring... 2017: 141). 
Given that only $1.5 \%$ of the population were surveyed in microcensus, we trust data from the 2010 Census to a greater extent (Table 8).

Table 8. Fertility rates in the cohorts of women born 1955-1985 in the Yamal-Nenets Autonomous Okrug and Russia as a whole

\begin{tabular}{|c|c|c|c|c|c|c|c|c|}
\hline \multirow[b]{2}{*}{$\begin{array}{c}\text { Year } \\
\text { of birth } \\
\text { of women }\end{array}$} & \multicolumn{4}{|c|}{ Yamal-Nenets Autonomous Okrug } & \multicolumn{4}{|c|}{ Russia } \\
\hline & 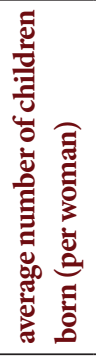 & 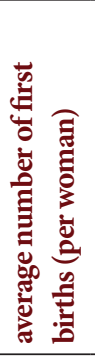 & 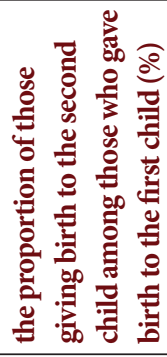 & 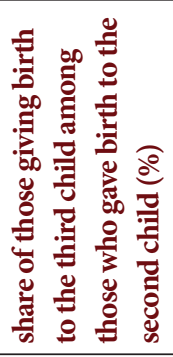 & 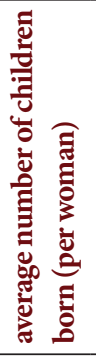 & 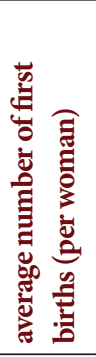 & 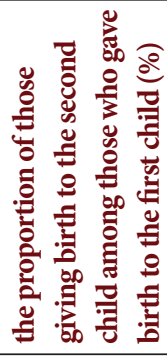 & 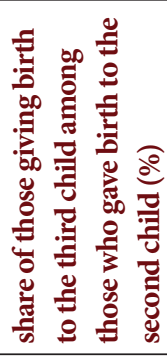 \\
\hline 1955 & 2.02 & 0.96 & 76.0 & 29.5 & 1.88 & 0.94 & 71.4 & 26.8 \\
\hline 1956 & 2.00 & 0.96 & 75.9 & 27.2 & 1.88 & 0.94 & 71.7 & 26.6 \\
\hline 1957 & 1.97 & 0.96 & 75.4 & 26.3 & 1.88 & 0.94 & 71.7 & 26.1 \\
\hline 1958 & 1.97 & 0.96 & 74.0 & 26.6 & 1.86 & 0.94 & 71.1 & 25.6 \\
\hline 1959 & 1.93 & 0.96 & 74.5 & 23.5 & 1.85 & 0.94 & 70.8 & 25.1 \\
\hline 1960 & 1.91 & 0.96 & 73.4 & 23.1 & 1.82 & 0.94 & 69.3 & 24.8 \\
\hline 1961 & 1.91 & 0.96 & 73.1 & 23.5 & 1.81 & 0.94 & 68.4 & 24.2 \\
\hline 1962 & 1.91 & 0.96 & 72.5 & 23.5 & 1.78 & 0.94 & 66.8 & 23.9 \\
\hline 1963 & 1.90 & 0.96 & 71.1 & 23.8 & 1.75 & 0.93 & 65.1 & 23.6 \\
\hline 1964 & 1.86 & 0.96 & 67.5 & 24.1 & 1.73 & 0.93 & 63.5 & 23.6 \\
\hline 1965 & 1.86 & 0.95 & 69.3 & 22.9 & 1.70 & 0.93 & 61.7 & 23.7 \\
\hline 1966 & 1.86 & 0.96 & 67.3 & 23.8 & 1.68 & 0.93 & 60.3 & 23.7 \\
\hline 1967 & 1.85 & 0.95 & 66.3 & 24.3 & 1.66 & 0.92 & 58.7 & 23.7 \\
\hline 1968 & 1.79 & 0.96 & 63.8 & 22.9 & 1.64 & 0.92 & 57.6 & 24.0 \\
\hline 1969 & 1.77 & 0.95 & 62.9 & 24.7 & 1.61 & 0.92 & 56.5 & 23.7 \\
\hline 1970 & 1.73 & 0.94 & 62.5 & 23.3 & 1.58 & 0.90 & 55.2 & 23.6 \\
\hline 1971 & 1.71 & 0.94 & 63.8 & 21.2 & 1.56 & 0.90 & 54.7 & 23.0 \\
\hline 1972 & 1.69 & 0.93 & 60.8 & 23.2 & 1.53 & 0.89 & 54.1 & 22.5 \\
\hline 1973 & 1.67 & 0.92 & 60.7 & 22.7 & 1.51 & 0.88 & 53.7 & 22.2 \\
\hline 1974 & 1.62 & 0.91 & 60.0 & 20.2 & 1.48 & 0.88 & 53.1 & 21.5 \\
\hline 1975 & 1.59 & 0.89 & 58.8 & 21.8 & 1.44 & 0.86 & 51.7 & 21.1 \\
\hline 1976 & 1.54 & 0.89 & 56.1 & 19.7 & 1.40 & 0.85 & 50.3 & 20.2 \\
\hline 1977 & 1.45 & 0.87 & 52.7 & 17.7 & 1.35 & 0.84 & 48.1 & 19.5 \\
\hline 1978 & 1.41 & 0.86 & 51.3 & 16.5 & 1.29 & 0.82 & 45.8 & 18.9 \\
\hline 1979 & 1.31 & 0.84 & 46.6 & 16.2 & 1.22 & 0.80 & 42.8 & 18.2 \\
\hline 1980 & 1.22 & 0.80 & 41.6 & 16.3 & 1.14 & 0.76 & 39.7 & 17.8 \\
\hline 1981 & 1.13 & 0.78 & 36.7 & 14.9 & 1.07 & 0.74 & 36.2 & 16.7 \\
\hline 1982 & 1.05 & 0.74 & 35.3 & 15.2 & 0.98 & 0.70 & 32.7 & 16.1 \\
\hline 1983 & 0.94 & 0.70 & 28.5 & 15.0 & 0.88 & 0.65 & 28.8 & 15.4 \\
\hline 1984 & 0.82 & 0.62 & 26.4 & 13.3 & 0.77 & 0.59 & 25.8 & 14.8 \\
\hline 1985 & 0.69 & 0.55 & 21.3 & 14.5 & 0.66 & 0.52 & 23.2 & 14.7 \\
\hline
\end{tabular}

Source: author's calculations according to the 2010 All-Russian Census 
Data from the 2010 Census show a decrease in the average number of children born in cohorts of the Yamal-Nenets Autonomous Okrug residents. If for women born in 1955 and 1956 it was 2.02 and 2.00 respectively, in women born in 1970 it was 1.73 (at the time of the 2010 Census they were 40 years old, and the average number of their children born until the end of the reproductive period still had to increase slightly). Let us emphasize, however, that these data date back to 2010. Calculations for other regions show that the decline in the average number of births continued until reaching the cohorts born in the early 1970s, and in younger women, it stabilized and even slightly grew. This increase is the result of two opposite trends: on the one hand, the average number of first births decreases, that is, the proportion of those who have given birth to at least one child, and on the other hand, increase both the proportion of those who have given birth to the second child among those who gave birth to the first and the proportion of those who have given birth to the third child among those who gave birth to the second child (Regional... 2019; Arkhangelsk 2019). The results of the next population census will show whether there is such a dynamics of fertility rates in cohorts of women in the Yamal-Nenets Autonomous Okrug.

The average number of children born in actual cohorts of women in the Yamal-Nenets Autonomous Okrug is higher than in Russia as a whole. In the generations of women born in 1955-1956, the difference is $0.12-0.14$ children per woman. Reducing slightly in women born in the late 1950s, it increases again, reaching 0.18-0.19 in women born in 1966-1967. In cohorts born in 1968-1976, it is 0.14-0.16. Thus, based on the data of the 2010 Census, it could be said that the difference in the average number of children born in actual cohorts of women in the Yamal-Nenets Autonomous Okrug and Russia as a whole remains roughly constant, with no pronounced dynamics to shrink or increase.

The average number of first births or births of at least one child is higher than the national overall. In the cohorts born in the early 1970s, which by the time of the 2010 Census had almost completed the process of childbearing for the first children, the difference is very significant, at 0.04 children per woman.

The main differences in the average number of children born between residents of the Yamal-Nenets Autonomous Okrug and the average Russian indicators are associated with second births. The proportion of births of the second child among those who gave birth to the first child in the Yamal-Nenets Autonomous Okrug has almost consistently declined, from $76.0 \%$ for women born in 1955 to $67.5 \%$ for women born in 1964 (at the time of the 2010 Census they were 46 years old and the process of having their second children was close to completion). In younger generations, given the likelihood of having a second child before the end of the reproductive period, it is possible to mention at least stabilization of the magnitude of this indicator. Whether it is true, can be determined from 2021 census data.

At that, we have to keep in mind, that the 2010 and 2021 Censuses data on the number of children born in actual cohorts may not be quite comparable due to differences in the population of women in these two censuses due to the significant migration mobility in the Yamal-Nenets Autonomous Okrug.

In most cohorts (starting with those born in 1955) who were no longer of reproductive age at the time of the 2010 Census, the proportion of those having a second child in the Yamal-Nenets Autonomous Okrug is higher than overall for Russia, by 4-6 percentage points. At the same time, the proportion of those who gave birth to a third child among women who gave birth to the second in actual cohorts in the Yamal-Nenets Autonomous Okrug is hardly different from the value of this indicator in Russia as a whole (Table 8). 
The average number of children born in actual cohorts of women varies significantly in municipal areas and urban districts of the Yamal-Nenets Autonomous Okrug (Table 9).

Table 9. Average number of children born in actual cohorts of women in municipal districts and urban districts of the Yamal-Nenets Autonomous Okrug

\begin{tabular}{lccccccccc}
\hline & \multicolumn{8}{c}{ Cohort birth years } \\
& $\mathbf{1 9 4 0 -}$ & $\mathbf{1 9 4 5 -}$ & $\mathbf{1 9 5 0 -}$ & $\mathbf{1 9 5 5 -}$ & $\mathbf{1 9 6 0 -}$ & $\mathbf{1 9 6 5 -}$ & $\mathbf{1 9 7 0 -}$ & $\mathbf{1 9 7 5 -}$ & $\mathbf{1 9 8 0 -}$ \\
& $\mathbf{1 9 4 4}$ & $\mathbf{1 9 4 9}$ & $\mathbf{1 9 5 4}$ & $\mathbf{1 9 5 9}$ & $\mathbf{1 9 6 4}$ & $\mathbf{1 9 6 9}$ & $\mathbf{1 9 7 4}$ & $\mathbf{1 9 7 9}$ & $\mathbf{1 9 8 4}$ \\
\hline & 1.78 & 2.05 & 2.26 & 2.08 & 1.83 & 1.95 & 1.59 & 1.50 & 1.34 \\
Krasnoselkupsky & 1.94 & & \\
Nadymsky & 2.23 & 2.00 & 1.91 & 1.92 & 1.82 & 1.72 & 1.61 & 1.39 & 0.95 \\
Priuralsky & 3.56 & 2.52 & 2.48 & 2.32 & 2.59 & 2.36 & 2.08 & 1.95 & 1.41 \\
Purovsky & 2.35 & 2.08 & 2.14 & 2.00 & 2.01 & 1.89 & 1.83 & 1.57 & 1.12 \\
Tazovsky & 3.06 & 3.25 & 2.74 & 2.53 & 2.67 & 2.71 & 2.29 & 2.01 & 1.33 \\
Shuryshkarskiy & 2.76 & 2.92 & 2.60 & 2.69 & 2.76 & 2.53 & 2.35 & 2.07 & 1.39 \\
Yamalsky & 3.50 & 2.77 & 2.75 & 2.90 & 2.65 & 2.94 & 2.43 & 1.88 & 1.60 \\
& & & Urban & Districts & & & & \\
Salekhard & 2.05 & 1.97 & 2.01 & 1.97 & 1.93 & 1.79 & 1.61 & 1.41 & 0.98 \\
Gubkinskiy & 2.11 & 1.60 & 1.91 & 1.83 & 1.64 & 1.63 & 1.56 & 1.41 & 0.94 \\
Labytnangi & 2.15 & 2.24 & 2.08 & 1.96 & 1.80 & 1.71 & 1.60 & 1.40 & 1.11 \\
Muravlenko & 2.29 & 1.93 & 1.96 & 1.95 & 1.84 & 1.73 & 1.66 & 1.41 & 1.05 \\
Novy Urengoy & 1.93 & 1.90 & 1.90 & 1.85 & 1.82 & 1.70 & 1.60 & 1.40 & 0.94 \\
Noyabrsk & 2.00 & 1.87 & 1.88 & 1.88 & 1.78 & 1.69 & 1.59 & 1.34 & 0.94 \\
\hline
\end{tabular}

Source: author's calculations according to the 2010 All-Russian Census data

Among municipal districts, the relatively higher average number of children born in actual cohorts of women, according to the 2010 Census, is observed in Tazovsky, Shuryshkar and Yamal districts. It is significantly lower in the Krasnoselkupsk, Nadymsky and Purovsky districts. Similar differences can be traced in the TFR in 2014-2017 (Table 2). However, it should be noted that if in the Nadym and Purov districts the TFR over these years is comparable to the average number of children born in actual cohorts, in the rest of the districts (in Krasnoselkupsky in 2014-2016) the TFR is substantially higher. This may be due either to a significant increase in the fertility rate since the 2010 Census in these areas, or to an underestimated number of women of reproductive age (overestimation of the number of births is difficult to assume) in population statistics.

In urban districts, the average number of children born in actual cohorts is comparable to the TFR, taking into account its increase since the 2010 Census. The differences in the average number of children born in actual cohorts in urban districts are relatively small (significantly less than in the municipal area; see Table 9).

\section{Conclusion}

The Yamal-Nenets Autonomous Okrug is one of the subjects of the Russian Federation with a relatively high fertility rate. This is evident both in the overall indicators affected by the age structure of the population and in age-specific and total fertility rates. 
The analysis of calendar fertility indicators testifies of their higher level compared to the All-Russian indicators for all births. At the same time, maximum differences are observed in third and subsequent births. At odds with this is the analysis of data on actual cohorts: it shows significant differences in second births. Thus, the proportion of women who gave birth to the second child among those who gave birth to the first in the Yamal-Nenets Autonomous Okrug is higher than in Russia overall, while the differences in the proportion of those giving birth to the third child among those who gave birth to the second child are small.

Data for actual cohorts refer to the 2010 Census, and a significant increase in birth rates for third and subsequent births is pronounced since 2012, when in the Yamal-Nenets Autonomous Okrug was lunched the programme of the regional maternal (family) capital. Its amount was set to 350 thousand rubles; since 2020 it has been increased to 500 thousand rubles, which is the largest sum across all Russian regions.

It is too early to talk about the possible impact of this increase in regional maternal (family) capital on real (cohort) birth rates. Note only that, according to preliminary data, in 2020 the total fertility rate in the region increased for the first time since 2015, and in terms of its increase (by 3.2\%), the Yamal-Nenets Autonomous Okrug ranked sixth in the country.

\section{Reference list}

Andreev EM, Zakharov SV (2017) Mikroperepis'-2015 stavit pod somnenie rezul'tativnost' mer po stimulirovaniyu rozhdaemos [Microcensus-2015 questions the effectiveness of measures to stimulate fertility]. Demoscope Weekly: 711-712. URL: http://demoscope.ru/weekly/2017/0711/tema01. php (accessed: 26.02.2021). (in Russian)

Andronov SV, Lobanov AA, Bogdanova EN, Popov AI, Kochkin RA, Lobanova LP, Kostritsyn VV, Protasova IV (2018) Problemy materinstva i detstva u zhitelei tundry i natsional'nykh poselkov Yamalo-Nenetskogo avtonomnogo okruga [Problems of motherhood and childhood in tundra residents and national settlements of the Yamal-Nenets Autonomous Okrug]. «Budushchee Arktiki nachinaetsya zdes'». Sbornik materialov II Vserossiiskoi nauchno-prakticheskoi konferentsii s mezhdunarodnym uchastiem ["The future of the Arctic begins here". Compedium of materials of the II All-Russian scientific-practical conference with international participation]: 170-6. URL: https:// www.elibrary.ru/download/elibrary_36923369_56419656.html (accessed: 26.02.2021). (in Russian)

Arkhangelsky VN, Dzhanaeva NG (2014) Regional'nye osobennosti dinamiki rozhdaemosti i demograficheskaya politika [Regional peculiarities of fertility dynamics and demographic policy]. Uroven' zhizni naseleniya regionov Rossii [Living Standards and Quality of Life]: 1(191): 73-82. https://doi.org/10.12737/3486 (in Russian)

Arkhangelsky VN (2019) Rozhdaemost' v real'nykh pokoleniyakh rossiiskikh zhenshchin: tendentsii i regional'nye razlichiya [Fertility in actual cohorts of Russian women: trends and regional differences]. Ehkonomika. Nalogi. Pravo [Economics. Taxes. Law]: 12(2): 59-69.

https://doi.org/10.26794/1999-849X-2019-12-2-59-69 (in Russian)

Fertility: System of Indicators and Methods of Analysis (2014) Demography for Practitioners / Rybakovsky LL (ed.). M.: Econ-Inform. P. 91-3 URL: http://rybakovsky.ru/uch1/10.html (in Russian)

Kombarova TV (2015) Dinamika rozhdaemosti v Tyumenskoi oblasti [Dynamics of fertility in the Tyumen oblast]. Demograficheskie protsessy na postsovetskom prostranstve. Sbornik materialov VI Ural'skogo demograficheskogo foruma s mezhdunarodnym uchastiem [Demographic processes 
in the post-Soviet space. Compedium of materials of the VI Ural Demographic Forum with international participation]. Yekaterinburg: I: 297-302. URL: https://www.elibrary.ru/download/ elibrary_24318516_77536752.pdf (accessed: 26.02.2021). (in Russian)

Muzykina YuA (2015) Mery sotsial'noi podderzhki mnogodetnym sem'yam v Yamalo-Nenetskom avtonomnom okruge [Measures of social support for large families in the Yamal-Nenets Autonomous Okrug]. Molodoi uchenyi [Young scientist]: 18 (98): 305-9. URL: https://moluch.ru/ archive/98/22071/ (accessed: 26.02.2021). (in Russian)

Regional features of demographic development of Russia in the 21st century (2019) Rybakovsky LL (ed.). M.: Econ-Inform. (in Russian)

Smulyanskaya NS (2017) Klassifikatsiya regionov Rossii po vozrastnym modelyam rozhdaemosti [Classification of the regions of Russia by age models of fertility]. Region: ehkonomika i sotsiologiya [Region: economics and sociology]: 3(95): 146-57. https://doi.org/10.15372/REG20170307 (in Russian) Zyryanova (Shishkina) MA (2018) Determinanty rozhdaemosti v severnykh regionakh Rossii: rezul'taty Vserossiiskikh perepisei naseleniya [Determinants of fertility in the northern regions of Russia: results of All-Russian population censuses]. Regionologiya [Regionology]: 26(2): 358-83. https://doi.org/10.15507/2413-1407.103.026.201802.358-383 (in Russian)

\section{Other data sources}

Address by the President of the Russian Federation to the Federal Assembly of the Russian Federation. December 3, 2015. URL: http://www.kremlin.ru/acts/bank/40542/page/2 (in Russian)

Demographic Yearbook of Russia (2019) Appendix. Federal State Statistic Service. URL: http://www. gks.ru/bgd/regl/B19_16/Main.htm (in Russian)

Demographic Yearbook of Russia (2017) Appendix. Federal State Statistic Service. URL: http://www. gks.ru/bgd/regl/B17_16/Main.htm (in Russian)

Demographic Yearbook of Russia (2015) Appendix. Federal State Statistic Service. URL: http://www. gks.ru/bgd/regl/B15_16/Main.htm (in Russian)

Demographic Yearbook of Russia (2014) Appendix. Federal State Statistic Service. URL: http://www. gks.ru/bgd/regl/B14_16/Main.htm (in Russian)

Demographic Yearbook of Russia (2013) Federal State Statistic Service. URL: http://www.gks.ru/bgd/ regl/B13_16/Main.htm (in Russian)

Demographic Yearbook of Russia (2012) Federal State Statistic Service. URL: http://www.gks.ru/bgd/ regl/B12_16/Main.htm (in Russian)

Law of the Yamal-Nenets Autonomous Okrug of July 01, 2011 No. 73-LAO "On Maternal (Family) Capital in the Yamal-Nenets Autonomous Okrug”. URL: http://docs.cntd.ru/document/422400855 (in Russian)

Law of the Yamal-Nenets Autonomous Okrug of February 09, 1998 No. 7-LAO "On State Youth Policy in the Yamal-Nenets Autonomous Okrug" (terminated 25.09.2009). URL: http://docs.cntd. $\mathrm{ru} /$ document/800100883 (in Russian)

Law of the Yamal-Nenets Autonomous Okrug of June 21, 2003 No. 39-LAO "On the District Target Programme "Housing for Young Families" (terminated 16.02.2005). URL: http://docs.cntd.ru/ document/473407905 (in Russian)

Law of the Yamal-Nenets Autonomous Okrug of November 29, 2019 No. 87-LAO “On Amendments to the Law of the Yamal-Nenets Autonomous Okrug "On Maternal (Family) Capital in the YamalNenets Autonomous Okrug”. URL: http://docs.cntd.ru/document/561618342 (in Russian) 
Monitoring of demographic development of Moscow. 2016-2017 (2017) Analytical materials. URL: https://docplayer.ru/91514547-Monitoring-demograficheskogo-razvitiya-moskvy.html (accessed: 26.02.2021). (in Russian)

Resolution of the Governor of the Yamal-Nenets Autonomous Okrug of October 29, 2001 No. 651 “On Approval of District Targeted Programmes" (terminated 01.09.2010) URL: http://pravo.gov. $\mathrm{ru} /$ proxy/ips/?docbody=\&prevDoc $=163013592 \&$ backlink $=1 \& \&$ nd $=163013563$ (in Russian)

\section{Information about the author}

- Vladimir Nikolaevich Arkhangelsky, Cand. Sci. (Econ.), Head of Sector at the Laboratory of Population Economics and Demography, Faculty of Economics, Lomonosov Moscow State University; Senior Researcher of the Laboratory of Population Reproduction Problems at the Institute of Socio-Economic Studies of Population, FCTAS RAS. E-mail: archangelsky@yandex.ru 